\title{
Analisis Kesalahan Siswa SMA dalam Menyelesaikan Soal Cerita Materi Matriks
}

\author{
Alifiana Mareta ${ }^{1}$, Cholis Sa'dijah ${ }^{2}$, Tjang Daniel Chandra ${ }^{3}$ \\ 1, 2,3 Program Studi Magister Pendidikan Matematika, Universitas Negeri Malang, \\ Jl. Semarang No. 05, Malang, Indonesia \\ alifianamareta@gmail.com
}

\begin{abstract}
This study aims to describe the characteristics of students' errors in solving the matrix material story questions so that appropriate actions can be taken so that the same error does not occur again. The research method used in this research is descriptive qualitative research because it aims to describe the mistakes made by students in solving problems. On March 24, 2021, as many as 36 students from class XI IPA 6 at SMAN 1 Sampang were involved in this research, but 2 students were selected to be analyzed in depth based on the number of mistakes made in completing the tracking instrument. Error analysis is carried out based on 1 matrix material story question. Student 1 and Student 2 made mistakes in three stages, namely in understanding the problem, errors in planning problem solving and errors in carrying out problem solving. Based on this research, it can be seen that students who have many misunderstandings in the prerequisite material will often make mistakes in the problem's solving stage in word problem.
\end{abstract}

Keywords: errors, matrix, word problem

\begin{abstract}
Abstrak
Penelitian ini bertujuan untuk mendeskripsikan karakteristik kesalahan siswa dalam menyesaikan soal cerita materi matriks sehingga dapat dilakukan tindakan yang tepat agar kesalahan yang sama tidak terjadi lagi. Metode penelitian yang digunakan dalam penelitian ini adalah penelitian deskriptif kualitatif karena bertujuan untuk mendeskripsikan kesalahan yang dilakukan oleh siswa siswa dalam menyelesaikan masalah. Pada 24 Maret 2021 sebanyak 36 siswa dari kelas XI IPA 6 di SMAN 1 Sampang terlibat dalam penelitian ini, namun dipilih 2 siswa yang akan dianalisis mendalam berdasarkan banyaknya kesalahanan yang dilakukan dalam menyelesaikan instrumen pelacak. Analisis kesalahan dilakukan berdasarkan 1 soal cerita materi matriks. Siswa 1 dan Siswa 2 melakukan kesalahan dalam tiga tahapan, yakni dalam memahami masalah, kesalahan dalam merencanakan penyelesaian masalah dan kesalahan dalam melaksanakan penyelesaian masalah. Berdasarkan dari penelitian tersebut dapat diketahui bahwa siswa yang memiliki banyak kesalahpahaman dalam materi prasyarat akan lebih sering melakukan kesalahan dalam tahapan penyelesaian masalah soal cerita.
\end{abstract}

Kata kunci: kesalahan, matriks, soal cerita

Copyright (c) 2021 Alifiana Mareta, Cholis Sa'dijah, Tjang Daniel Chandra

Corresponding author: Alifiana Mareta

Email Address: alifianamareta@gmail.com (Jl. Semarang No. 05, Malang, Indonesia)

Received 19 April 2021, Accepted 24 April 2021, Published 10 May 2021

\section{PENDAHULUAN}

Matematika dikembangkan menjadi salah satu pelajaran sebagai sarana untuk meningkatkan kemampuan literasi numerasi siswa yang diusung oleh pemerintah. Kemampuan literasi numerasi siswa dalam pelajaran matematika akan memberikan dampak yang nyata dalam kehidupan. Pemerintah mengatakan bahwa apabila banyak orang yang dapat mengaplikasikan kemampuan matematis di dalam konteks ekonomi, teknik, sains, sosial, dan bidang lainnya, daya saing ketenagakerjaan dan kesejahteraan ekonomi akan meningkat (Kemendikbud, 2017). Namun, matematika masih menjadi salah satu mata pelajaran yang dianggap sulit dan tidak menyenangkan bagi siswa (Farida, 2015).

Siswa harus memiliki kemampuan menyelesaikan masalah yang merupakan salah satu kemampuan matematis yang harus dimiliki dalam pembelajaran matematika (NCTM, 2000). Penyelesaian masalah dalam matematika terdiri atas beberapa tahapan. Tahapan dalam menyelesaikan 
masalah menurut Polya (dalam Argarini, 2018) terdiri atas empat langkah, yaitu : 1) Memahami masalah yang merupakan tahapan dimana siswa dapat menggambarkan atau mengidentifikasikan masalah yang disajikan. Proses identifikasi dapat dilakukan melalui membaca masalah yang disajikan, mendengar atau mengamati keadaan sekitar. 2) Merencanakan penyelesaian masalah merupakan tahapan dimana siswa dapat menemukan koneksi atau hubungan data yang tersedia dan hal lain untuk pertimbangan pemecahan masakah. 3) Melaksanakan perencanaan merupakan tahapan dimana siswa melaksanakan rencana yang telah disusun pada langkah sebelumnya untuk menyelesaikan masalah. 4) Memeriksa kembali merupakan tahapan terakhir dimana siswa memriksa ulang setiap langkah penyelesaian atau dengan menguji hasil selesaian yang diperoleh dan memberikan kesimpulan.

Soal cerita merupakan salah satu bentuk soal matematika yang dapat dijadikan soal pemecahan masalah dalam meningkatkan kemampuan literasi dan numerasi. Soal matematika yang disajikan dalam bentuk soal cerita dapat berupa masalah kontekstual yang berhubungan dengan kehidupan sehari-hari sehingga dapat membuat siswa lebih memahami isi soal (Rahmania \& Rahmawati, 2016). Namun, masih banyak siswa menganggap soal cerita sebagai soal yang sulit karena mereka kurang memahami inti atau maksud dari soal cerita tersebut. Seperti halnya penelitian yang dilakukan oleh Jumiati \& Zanthy (2020) bahwa siswa masih melakukan kesalahan dalam memisalkan variabel dan siswa beranggapan bahwa soal cerita lebih sulit dari soal biasa. Penelitian yang dilakukan oleh Mubarokah \& Nusantara (2020) menunjukkan bahwa siswa banyak melakukan kesalahan dalam pemodelan matematika apabila soal disajikan dalam bentuk soal cerita.

Berdasarkan wawancara dengan salah seorang guru di SMAN 1 Sampang, lebih dari 50\% siswa dalam satu kelas menganggap soal matematika sulit dan mereka juga melakukan kesalahan dalam menyelesaikan soal matematika yang berbentuk soal cerita. Pemecahan masalah dalam matematika merupakan suatu proses menemukan jawaban atau solusi dari suatu pertanyaan yang terdapat dalam suatu cerita, teks, tugas dan situasi dalam kehidupan sehari-hari (Yarmani, 2016). Penelitian yang dilakukan oleh Farida (2015) menyatakan bahwa siswa mengalami kesulitan dalam menyelesaikan soal cerita yang menyebabkan terjadinya kesalahan dalam proses penyelesaiannya.

Salah satu guru di SMAN 1 Sampang juga mengatakan bahwa dalam materi matriks soal lebih banyak diberikan dalam bentuk angka seperti dalam Gambar 1. Soal yang hanya berbentuk angka atau model matematika tersebut hanya membutuhkan satu kali langkah penyelesaian, sehingga tidak nampak proses atau tahapan penyelesaian masalahnya. Matriks sendiri merupakan salah satu mata pelajaran yang dianggap sulit oleh siswa.

$$
\left|\begin{array}{ccc}
3 & 2 & -3 \\
4 & -3 & 1 \\
0 & 5 & -2
\end{array}\right|=\ldots .
$$


Materi matriks dapat disajikan dalam soal berbentuk soal cerita sehingga dalam penyelesaiannya kita dapat mengetahui langkah pemecahan masalah yang dilakukan oleh siswa. Berdasarkan langkahlangkah tersebut akan nampak proses untuk mendapatkan model matematika serta hasilnya dan akan nampak dimana letak kesalahan siswa untuk setiap tahapannya. Putri \& Putri (2016) yang mengatakan kesalahan dalam mengerjakan soal cerita juga ditemukan pada saat pembelajaran di kelas berlangsung dan dilakukan oleh siswa mengalami kesulitan belajar dan menjawab soal cerita. Siswa merasa kesulitan dalam memahami masalah yang berbentuk soal cerita dan kebingungan dalam menafsirkan ke dalam model matematika.

Berdasarkan hal tersebut, maka indikator kesalahan siswa yang digunakan dalam penelitian ini, yaitu : 1) kesalahan dalam memahami soal, 2) kesalahan dalam membuat rencana penyelesaian, 3) kesalahan dalam melaksanakan rencana penyelesaian, dan 4) kesalahan dalam memeriksa ulang jawaban dan menuliskan jawaban akhir soal. Soal yang diberikan kepada siswa berupa soal cerita materi matriks. Tujuan dalam penelitian ini untuk mendeskripsikan terkait kesalahan yang dilakukan oleh siswa dalam mengerjakan soal cerita materi matriks, sehingga dapat diberikan tindakan yang tepat agar kesalahan tidak terulang kembali.

\section{METODE}

Penelitian ini meruapakan penelitian deskriptif kualitatif karena bertujuan untuk mendeskripsikan kesalahan siswa dalam menyelesaikan soal cerita pada materi matriks. Sesuai dengan pendapat Putri dan Putri (2016) suatu gejala, peristiwa, atau kejadian yang terjadi dapat dijelaskan atau dideskripsikan. Penelitian deskriptif ini mengambil masalah atau memusatkan perhatian kepada masalah-masalah aktual sebagaimana adanya pada saat penelitian dilaksanakan. Sedangkan (Creswell, 2012) menyatakan bahwa penelitian kualitatif menggunakan data yang di dapat dari wawancara, pengamatan, dan dokumen; menganalisis teks dan gambar; dan menafsirkan inti dan pola yang terdapat di dalam data. Oleh karena itu, penelitian ini menggunakan dokumentasi yang berupa hasil pekerjaan siswa dalam menyelesaikan soal yang digunakan untuk mengumpulkan data, menganalisis, dan menafsirkan inti yang terdapat di dalam data.

Pada 24 Maret dilakukan penelitian kepada siswa kelas XI IPA 6 di SMAN 1 Sampang. Sebanyak 36 siswa SMA diberi pertanyaan matematika yang berupa instrumen pelacak tentang materi prasyarat terkait matriks. Materi prasyarat yang disajikan dalam instrumen pelacak berupa materi tentang persamaan linear dan sistem persamaan liner dua variabel. Isntrumen pelacak tersebut digunakan untuk mengetahui kesalahpahaman siswa dalam memahami materi prasyarat terkait matriks. Dari 36 siswa yang mengerjakan instrumen pelacak, hanya 2 siswa yang digunakan sebagai peserta dalam penelitian ini, yakni yang memiliki kesalahpahaman terbanyak saat menjawab pernyataan pada instrumen pelacak. Kesalahpahaman seperti itu berpotensi menyebabkan konflik kognitif pada siswa yang dapat menyebabkan terjadinya kesalahan. Masalah yang diberikan kepada siswa disajikan dalam Gambar 2. 
1. Ari dan teman-temannya membeli camilan di kantin. Ia memesan 3 bungkus stik balado dan 2 bungkus keripik singkong. Tak lama kemudian, Bima dan teman-temannya datang untuk membeli camilan juga. Ia membeli 5 bungkus stik balado dan 3 bungkus keripik singkong. Ari kemudian harus membayar Rp70.000,00 untuk semua camilan yang dibelinya, dan Bima harus membayar Rp115.000,00 untuk semua camilan yang dibelinya. Ari menantang Bimauntuk menebak camilan mana yang lebih mahal.
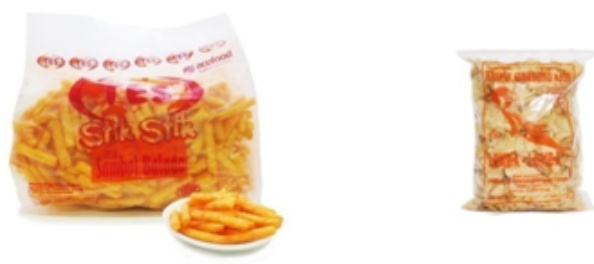

Bantulah Bima untuk menemukan harga camilan yang lebih mahal dengan menghitung harga satu bungkus stik balado dan harga satu bungkus keripik singkong dengan mengerjakan sesuai dengan uratan perintah di bawah ini!

a. Sebutkan dua nama orang dalam soal, nama camilan dan banyaknya bungkus masingmasing camilan yang dibeli, sertajumlah pembayarannya!

b. Ambil dua huruf alfabet (a, b, c, d, x, y, z, p, q, r, s, ...) untuk mengganti banyaknya bungkus camilan yang dibeli, dan tuliskan fakta tentang hubungan dari pembelian yg dilakukan Ari dan yang dilakukan Bima!

c. Tuliskan nama hubungan matematis yang menyatakan pembelian Ari atau pembelian Bima! Tuliskan gabungan pembelian Ari dan Bima dalam bilangan-bilangan yanng disusun berdasarkan aturan baris dan kolom berbentuk persegi panjang dan tuliskan nama hubungan matematis penggabungan yang diperoleh dari pembelian Ari dan Bima tersebut!

d. Tentukan nilai variabel dari hubungan matematis yang telah kamu peroleh menggunakan nilai determinan berdasarkan pengetahuan dan keterampilan yang sudah kamu miliki!

e. Bagaimana kamu yakin terhadap jawaban yang sudah kamu peroleh?

f. Apa jawaban permasalahan yang kamu temukan? Camilan manakah yang lebih mahal?

Gambar 2. Masalah yang Diberikan kepada Siswa

Berdasarkan soal pada Gambar 2, peneliti membuatnya terbagi dalam tahapan penyelesaian masalah. Tahapan penyelesaian masalah yang digunakan adalah milik Polya. Pada tahap pertama yaitu tahapan memahami masalah terletak pada soal nomor 1a, 1b, dan 1c. Jawaban untuk soal tersebut digunakan sebagai tahapan pertama siswa untuk memahami masalah terkait matriks. Tahapan selanjutnya, yaitu untuk merencanakan penyelesaian dan melaksanakan rencana penyelesaian ada pada nomor 1d. Pada tahap ini menentukan bagaimana cara atau rumus yang akan digunakan oleh siswa serta cara penyelesaiannya. Sedangkan untuk tahap terakhir, yaitu memeriksa kembali jawaban dan membuat kesimpulan untuk jawaban terdapat pada soal nomor 1e dan 1f. Soal 1e menuntut siswa untuk mengecek 
kembali jawaban yang diperoleh dan soal 1f menuntut jawaban akhir siswa sebagai kesimpulan untuk masalah yang telah diberikan.

\section{HASIL DAN DISKUSI}

\section{Hasil}

Pengambilan subjek penelitian diambil dengan memberikan instrumen pelacak yaitu 10 soal jawaban singkat terkait materi prasyarat untuk matriks dan instrumen utama yang berisi 1 soal cerita materi matriks. Hasil dari pengerjaan siswa untuk instrumen pelacak terlebih dahulu dikoreksi berapa banyak kesalahpahaman yang terjadi kepada siswa. Selanjutnya, peneliti menghitung banyaknya kesalahpahaman yang terjadi. Berikut adalah tabel banyaknya kesalahpahaman siswa dalam menjawab instrumen pelacak dan kesalahan dalam menjawab instrumen utama:

Tabel 1. Banyaknya Kesalahpahaman Siswa

\begin{tabular}{|l|l|l|}
\hline Banyak Kesalahpahaman & Banyak Siswa & Persentase Siswa \\
\hline $1-3$ soal & 6 & $16,7 \%$ \\
\hline $3-6$ soal & 28 & $77,8 \%$ \\
\hline $7-10$ soal & 2 & $5,5 \%$ \\
\hline
\end{tabular}

Berdasarkan Tabel 1 tersebut terdapat dua siswa yang memiliki kesalahpahaman terbanyak saat menjawab instrumen pelacak. Selanjutnya, hasil pengerjaan dua siswa tersebut pada isntrumen utama diambil untuk dilakukan analisis terkait kesalahan dalam pengerjaan soal cerita. Analisis kesalahan siswa akan didasarkan pada indikator kesalahan yang sudah dijelaskan dalam penelitian ini, yaitu : kesalahan memahami soal, kesalahan membuat rencana penyelesaian, kesalahan melaksanakan rencana penyelesaian, dan kesalahan memeriksa kembali jawaban. Ringkasan hasil penelitian analisis pemecahan masalah materi matriks untuk dua siswa tersebut lebih lengkap akan dijelaskan sebagai berikut:

\section{Hasil Analisis Kesalahan Jawaban Siswa 1}

Hasil dari kesalapahaman Siswa 1 saat menjawab instrumen pelacak adalah sebanyak 7 soal. Berdasarkan hal tersebut, maka kita akan menganalisis jawaaan Siswa 1 dalam menjawab instrumen utama yang berupa soal cerita pada materi matriks. Adapun jawaban Siswa 1 dalam menyelesaikan masalah dapat dilihat pada Gambar 3. Pada tahap memahami masalah, Siswa 1 menuliskan jawaban untuk soal nomor 1a yang meminta informasi terkait nama orang, nama camilan yang dibeli, serta banyaknya camilan yang dibeli dituliskan ke dalam bentuk tabel. Siswa 1 tidak mengalami kesulitan dalam menuliskan kembali informasi dalam soal nomor 1a. Namun, pada soal nomor $1 \mathrm{~b}$ terdapat kesalahan yang dilakukan oleh Siswa 1 dalam memisalkan variabel. Hal tersebut juga nampak dalam jawaban Siswa 1 pada instrumen pelacak, yaitu Siswa 1 mengalami kesalahpahaman terkait pemisalan untuk suatu variabel. Hal tersebut mengindikasikan bahwa pemahaman siswa terkait variabel kurang baik (Marpa, 2019). Siswa 1 menunjukkan bahwa ia tidak dapat memahami maksud soal nomor $1 \mathrm{~b}$, tetapi tidak dapat menuliskan pemisalan variabel dengan benar. Pada nomor 1c juga terdapat kesalahan, 
Siswa 1 tidak memahami hubungan yang terbentuk. Berdasarkan fakta tersebut terlihat bahwa Siswa 1 melakukan kesalahan konsep khususnya pada indikator memahami soal (Rahmania \& Rahmawati, 2016).

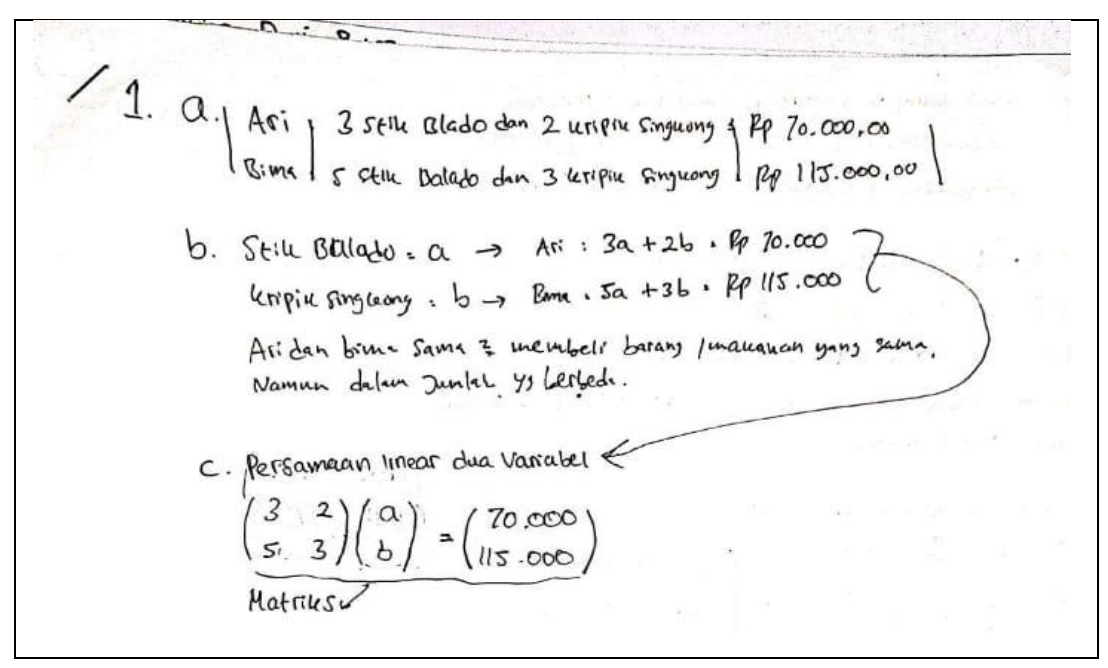

Gambar 3. Hasil Pekerjaan Siswa 1 Nomor 1a, 1b, 1c

Tahap yang kedua adalah tahap merencanakan penyelesaian. Terlihat dalam hasil jawaban Siswa 1 untuk nomor 1d adalah menggunakan invers matriks. Selanjutnya pada tahap melaksanakan penyelesaian terdapat kesalahan dalam melakukan operasi hitung pada perkalian matriks. Siswa 1 melakukan kesalahan operasi karena terdapat kesalahan dalam perhitungan yakni dalam melakukan operasi perkalian matriks belum melakukannya dengan benar (Jumiati \& Zanthy, 2020). Terlihat dalam hasil dari perkalian dua matriks yang dilakukan Siswa 1 tersebut lupa memberikan tanda penjumlahan. Tahap terakhir adalah memeriksa ulang jawaban dan menuliskan jawaban akhir dari soal. Pada tahap ini, tidak ada kesalahan operasi hitung yang dilakukan oleh Siswa 1, namun bukannya memeriksa kembali jawaban yang diperoleh dari nomor 1d akan tetapi Siswa 1 justru menuliskan alternatif penyelesaian apabila menggunakan metode substitusi dan eliminasi.

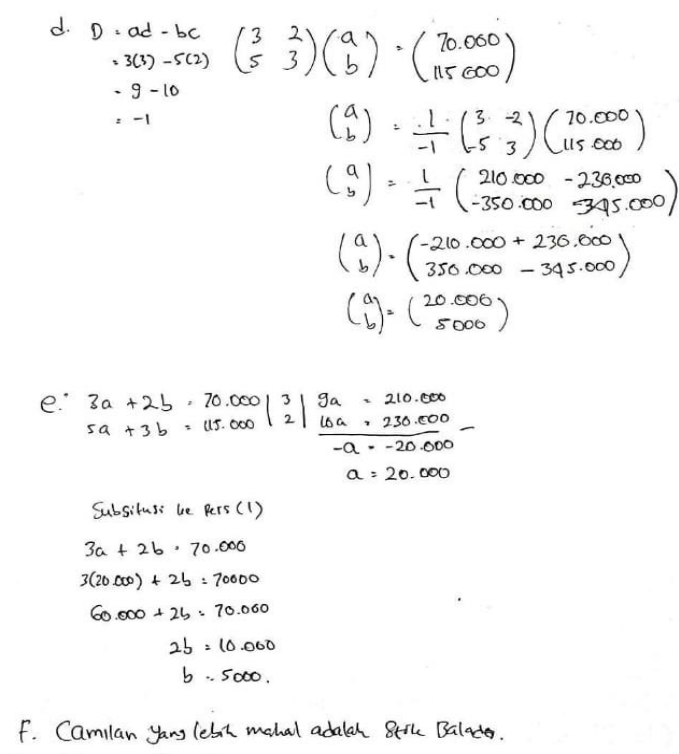

Gambar 4. Hasil Pekerjaan Siswa 1 Nomor 1d, 1e, 1f 


\section{Hasil Analisis Kesalahan Jawaban Siswa 2}

Hasil dari kesalapahaman Siswa 2 saat menjawab instrumen pelacak sebanyak 8 soal. Berdasarkan hal tersebut, maka kita akan menganalisis jawaaan Siswa 2 dalam menjawab instrumen utama yang berupa soal cerita pada materi matriks. Adapun jawaban Siswa 2 adalah sebagai berikut:

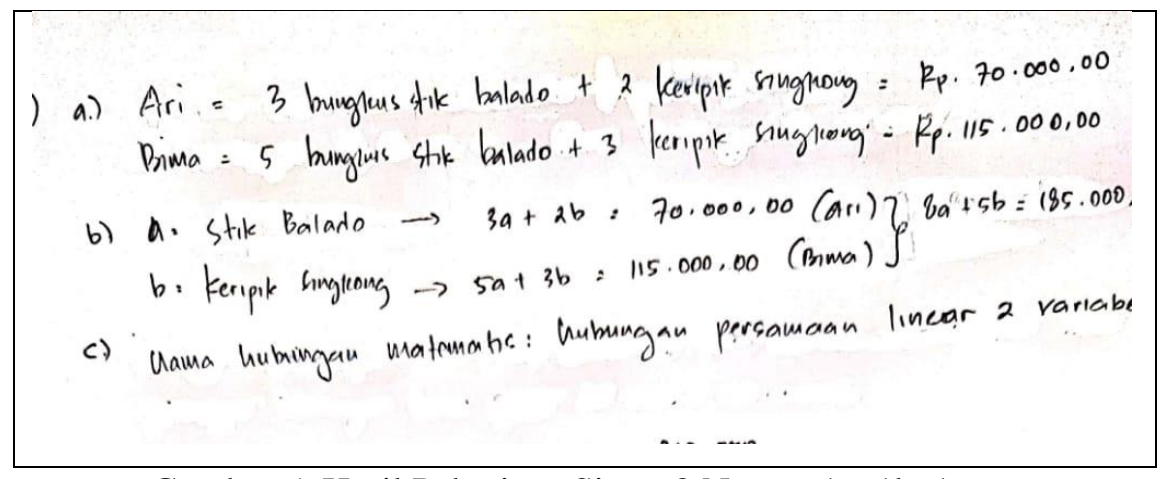

Gambar 5. Hasil Pekerjaan Siswa 2 Nomor 1a, 1b, 1c

Pada tahap memahami masalah, Siswa 2 menuliskan jawaban yang salah untuk soal nomor 1a yang meminta informasi terkait nama orang, nama camilan yang dibeli, serta banyaknya camilan yang dibeli karena dituliskan ke dalam bentuk penjumlahan. Berdasarkan pengerjaan tersebut terjadi kesalahan yang dilakuka oleh Siswa 2. Siswa 2 salah dalam merepresentasikan informasi dalam masalah karena salah dalam memaknai sitem persamaan linear dua variabel (Nurrahmawati, Sa'dijah, Sudirman, $\&$ Muksar, 2021). Sama seperti Siswa 1, pada soal nomor 1b terdapat kesalahan yang dilakukan oleh Siswa 2 dalam memisalkan variabel. Siswa 2 menunjukkan bahwa ia tidak dapat memahami maksud soal nomor $1 \mathrm{~b}$ dengan tidak dapat menuliskan pemisalan variabel dengan benar. Pada nomor 1c juga terdapat kesalahan, Siswa 2 tidak memahami hubungan yang terbentuk untuk gabungan pembelian Ari dan Bima yang terdapat dalam soal. Berdasarkan fakta tersebut terlihat bahwa Siswa 2 melakukan kesalahan konsep khususnya pada indikator memahami soal karena tidak dapat merepresentasikan fakta dalam soal cerita ke dalam bentuk model matematis yang diminta soal dengan benar (Ardiawan, 2015).

Tahap yang kedua adalah tahap merencanakan penyelesaian. Terlihat dalam hasil jawaban Siswa 2 untuk nomor 1d adalah menggunakan metode substitusi yang berbeda dengan yang diminta oleh soal. Selanjutnya pada tahap melaksanakan penyelesaian nomor 1e terlihat bahwa terdapat kesalahan prosedural karena Siswa 2 tidak menggunakan rumus yang diminta di dalam soal (Ardiawan, 2015). Siswa 2 tidak menggunakan determinan atau invers matriks dalam menjawab soal tersebut. Siswa 2 justru menggunakan penyelesaian metode substitusi dan eliminasi yang merupakan alternatif cara lain dalam menjawab soal bentuk sistem persamaan linear dua variabel. Sedangkan pada tahap terakhir, yaitu memeriksa ulang jawaban dan menuliskan jawaban akhir dari soal tidak ada kesalahan yang dilakukan oleh Siswa 2. 


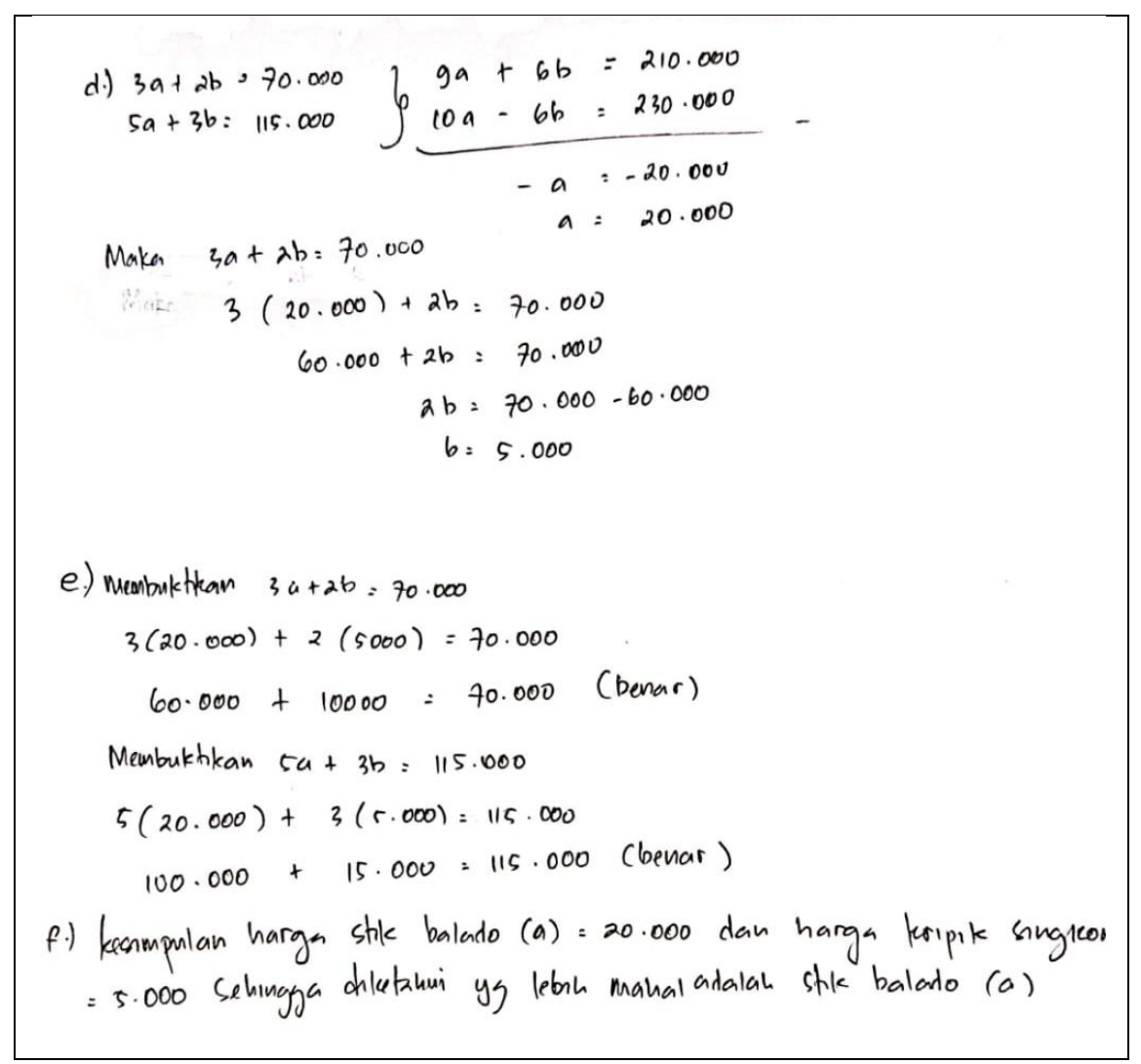

Gambar 6. Hasil Pekerjaan Siswa 2 Nomor 1d, 1e, 1f

\section{Diskusi}

\section{Pembahasan Kesalahan Siswa dalam Menyelesaikan Soal Cerita}

Tahap pertama dalam menyelesaikan soal cerita tersebut adalah tahap memahami masalah. Memahami masalah merupakan tahapan dimana siswa dapat menyebutkan atau mengidentifikasikan apa saja yang diketahui dari masalah yang disajikan (Febriyanti \& Novitasari, 2019). Proses identifikasi dapat dilakukan melalui membaca masalah yang disajikan dalam soal. Pada soal cerita matriks tersebut Siswa 1 dan Siswa 2 keduanya melakukan kesalahan dalam tahap ini. Informasi tentang soal cerita matriks tersebut dapat dituliskan dalam bentuk tabel atau kalimat. Siswa 1 menuliskannya dengan benar, sedangkan Siswa 2 menuliskannya dengan salah. Selanjutnya Siswa 1 dan Siswa 2 sama-sama melakukan kesalahan dalam memisalkan variabel dalam menjawab soal cerita tersebut. Kesalahan tersebut merupakan kesalahan konsep yang terjadi karena siswa tidak mengetahuhi konsep dari variabel dengan benar (Ardiawan, 2015). Kesalahan konsep juga terlihat saat Siswa 2 tidak dapat mengetahui bahwa dari sistem persamaan linear yang ada bisa dibentuk persamaan matriks, sedangkan Siswa 1 salah dalam menyebutkan nama hubungan dalam pemodelan matematis tersebut.

Tahap yang kedua adalah tahap merencanakan penyelesaian masalah. Merencanakan penyelesaian masalah merupakan tahapan dimana siswa dapat menemukan hubungan dari data yang tersedia dan hal lain untuk pertimbangan dalam menyelesaikan masalah sesuai pengetahuan yang sudah dimiliki (Ardiawan, 2015). Pada tahap penyelesaian masalah, peneliti menuliskan perintah dengan jelas untuk memanfaat nilai determinan matriks dalam mencari nilai variabel. Siswa 1 memanfaatkan nilai 
determinan matriks sedangkan Siswa 2 tidak memanfaatkan nilai determinan matriks seperti yang diminta penulis dikarenakan tidak memahami konsep terkait matriks.

Tahap ketiga melaksanakan perencanaan dalam menyelesaikan masalah. Melaksanakan perencanaan merupakan tahapan dimana siswa melaksanakan rencana yang telah disusun pada langkah sebelumnya untuk menyelesaikan masalah (Febriyanti \& Novitasari, 2019). Siswa 1 melaksanakan rencana selesaikan dengan memanfattkan determinan matriks dan menggunakan rumus invers matriks untuk mendapatkan selesaiannya. Namun, terdapat kesalahan dalam melakukan operasi hitung saat Siswa 1 melakukan perkalian dua matriks. Siswa 1 lupa menambahkan tanda "+" dalam menuliskan pada elemen matriks dari hasil perkalian dua matriks tersebut. Siswa 2 melakukan kesalahan fatal karena tidak mengikuti perintah soal yang meminta untuk memanfaatkan nilai determinan. Siswa diharuskan memberikan jawaban atau penyelesaian dalam memecahkan masalah matematika harus sesuai dengan perintah soal yang diajukan pada lembar pemecahan masalah (Sa'dijah, Rafiah, Gipayan, Qohar, \& Anwar, 2016).

Tahap terakhir adalah memeriksa ulang jawaban dan menuliskan jawaban akhir dari soal. Pada tahap ini siswa memeriksakan kembali hasil nilai variabel yang diperoleh ke dalam salah satu persamaan linear dua variabel yang dituliskan di awal (Purnamasari \& Setiawan, 2019). Siswa 1 menuliskan alternatif penyelesaian lain untuk memeriksa hasil jawaban tersebut, yaitu menggunakan metode substitusi dan eliminasi. Siswa 2 memeriksa kembali jawaban dengan mengujinya pada kedua persamaan linear dau variabel yang diperoleh sebelunya. Siswa 1 dan Siswa 2 juga mampu menarik kesimpulan untuk jawban akhir permasalahan dengan benar.

\section{KESIMPULAN}

Berdasarkan hasil penelitian dan pembahasan diketahui bahwa kesalahan yang dilakukan oleh subjek penelitian dalam menyelesaikan soal cerita matriks adalah kesalahan dalam memahami masalah. Kesalahan dalam memahami masalah berupa kesalahan konsep yang terlihat dari subjek penelitian tidak dapat menuliskan ulang informasi dalam soal ke dalam bentuk kata-kata atau tabel dan tidak dapat menuliskan pemisalan variabel dengan benar. Kesalahan yang kedua adalah dalam merencanakan penyelesaian, yaitu subjek penelitian tidak bisa memanfaatkan nilai determinan yang dimunta dalam soal dalam menyelesaikan masalah yang diberikan. Kesalahan yang ketiga berupa kesalahan melaksanakan penyelesaian. Subjek yang melakukan kesalahan dalam melaksanakan penyelesaian berupa kesalahan prosedural karena tidak bisa menggunakan determinan matriks dalam menyelesaikan masalah dan kesalahan operasi hitung karena tidak menuliskan hasil dari perkalian matriks dengan benar.

Berdasarkan pada penelitian ini nampak bahwa siswa dalam menyelesaikan soal cerita masih sering melakukan kesalahan. Kesalahan tersebut perlu diberikan tindakan sehingga kesalahan yang sama tidak terulang lagi. Oleh karena itu, diharapkan pengajar mampu merancang pembelajaran yang dapat 
Analisis Kesalahan Siswa SMA dalam Menyelesaikan Soal Cerita Materi Matriks, Alifiana Mareta, Cholis Sa'dijah, Tjang Daniel Chandra

memfasilitasi siswa untuk dapat mengembangkan pembelajaran yang dapat melatih kemampuan siswa dalam menyelesaikan masalah dalam soal cerita.

\section{UCAPAN TERIMA KASIH}

Penulis mengucapkan syukur kepada Allah SWT yang memberikan kelancaran dalam menyelesaikan penelitian dan artikel ini. Saya juga mengucapkan terimakasih kepada orang tua dan keluarga yang memberikan dukungan secara mental. Rasa terimakasih juga tidak lupa diucapkan kepada Prof. Dr. Cholis Sa'dijah, M.Pd., M. A. dan Drs. Tjang Daniel Chandra, M.Si., Ph.D selaku pembimbing tesis saya. Tidak lupa juga saya ucapkan terimakasih kepada guru dan siswa dari SMA Negeri 1 Sampang yang memberikan kesempatan untuk melakukan penelitian di sekolah tersebut.

\section{REFERENSI}

Ardiawan, Y. (2015). Analisis Kesalahan Mahasiswa dalam Menyelesaikan Soal Induksi Matematika di IKIP PGRI Pontianak. Jurnal Pendidikan Informatika Dan Sains, 4(1), 147-163. Retrieved from https://journal.ikippgriptk.ac.id/index.php

Argarini, D. F. (2018). Analisis Pemecahan Masalah Berbasis Polya pada Materi Perkalian Vektor Ditinjau dari Gaya Belajar. Jurnal Ilmiah DIKDAYA, 6(1), 12-19. https://doi.org/10.33477/mp.v6i1.448

Creswell, J. W. (2012). Educational Research : Planning, Conducting, and Evaluating Quantitative and Qualitative Research.

Farida, N. (2015). Analisis Kesalahan Siswa SMP Kelas VIII dalam Menyelesaikan Masalah Soal Cerita Matematika. Aksioma, 151(2), 10-17.

Febriyanti, R., \& Novitasari. (2019). Pola Pemecahan Masalah Matematika pada Siswa yang Berkemampuan Setara. Vygotsky Journal, 1(2), 56-64.

Jumiati, Y., \& Zanthy, L. S. (2020). Analisis kesalahan siswa dalam menyelesaikan soal cerita persamaan dan pertidaksamaan linear satu variabel. Jurnal Pembelajaran Matematika Inovatif, 3(1), 11-18. https://doi.org/10.22460/jpmi.v3i1.p11-18

Kemendikbud. (2017). Materi Pendukung Literasi Numerasi. In Mayani \& L. Anik (Eds.), Kementerian Pendidikan dan Kebudayaan. Jakarta.

Marpa, E. P. (2019). Common Errors in Algebraic Expressions: A Quantitative-Qualitative Analysis. International Journal on Social and Education Sciences, 1(2), 63-72. https://doi.org/10.46328/ijonses.11

Mubarokah, I., \& Nusantara, T. (2020). Analisis Kesalahan Siswa Dalam Memodelkan Matematika Program Linear. Jurnal Pendidikan Matematika Undiksha, 11(2), 2599-2600. Retrieved from https://ejournal.undiksha.ac.id/index.php/JJPM/article/view/24716 
NCTM. (2000). Principles and Standards for School Mathematics. United States of America: The National Council of Teachers of Mathematics, Inc.

Nurrahmawati, Sa'dijah, C., Sudirman, \& Muksar, M. (2021). Assessing students' errors in mathematical translation: From symbolic to verbal and graphic representations. International Journal of Evaluation and Research in Education, 10(1), 115-125. https://doi.org/10.11591/ijere.v10i1.20819

Purnamasari, I., \& Setiawan, W. (2019). Analisis Kemampuan Pemecahan Masalah Matematis Siswa SMP pada Materi SPLDV Ditinjau dari Kemampuan Awal Matematika. Journal of Medives: Journal of Mathematics Education IKIP Veteran Semarang, 3(2), 207. https://doi.org/10.31331/medivesveteran.v3i2.771

Putri, W. A. S., \& Putri, A. (2016). Kemampuan Pemecahan Masalah Siswa SMA pada Materi Apikasi Matriks. Journal On Education, 01(03), 275-280.

Rahmania, L., \& Rahmawati, A. (2016). Analisis Kesalahan Siswa dalam Menyelesaikan Soal Cerita Persamaan Linier Satu Variabel. JMPM: Jurnal Matematika Dan Pendidikan Matematika, 1(2), 165. https://doi.org/10.26594/jmpm.v1i2.639

Sa'dijah, C., Rafiah, H., Gipayan, M., Qohar, A., \& Anwar, L. (2016). Asesmen Pemecahan Masalah Open-Ended untuk Mengukur Profil Berpikir Kreatif Matematis Siswa Berdasar Gender. Sekolah Dasar, (2), 147-159.

Yarmani, A. (2016). Analisis Kemampuan Pemecahan Masalah Matematis Siswa Kelas XI MIPA SMA Negeri 1 Kota Jambi. Jurnal Ilmiah DIKDAYA, 6(2), 12-19. 